\title{
Development and Characteristics of Social Work and Social Welfare in Korea
}

\author{
Kim Young-Hwa \\ Kyungpook National University, Korea \\ *Corresponding Author: yhwkim@knu.ac.kr
}

Copyright (C) 2013 Horizon Research Publishing All rights reserved.

\begin{abstract}
The beginning of social work and its formation differ in each society due to its unique historical and social background inherent to a society, so the beginning of social work in Korea is also categorically influenced by historical events. How social work in Korea began and why the expression 'social work' is no longer used and has been replaced by 'social welfare' can be understood in the context of the social work development process in Korea, as the change of word usage can be viewed as a product of history that reflects its epoch and society. Up until around 1980, all the work in this field had been called 'social work', thereafter the terminology 'social welfare' was used, but there is no longer any differentiation between these two terms as the microscopic approach of social work on personal services and the macroscopic approach of social policy are jointly called 'social welfare'. This research is to consolidate the details and characteristics of social work and social welfare development in Korea. Consequently, this paper focused how social work in Korea started, what are the patterns of social welfare development, and what are the prospects and problems of social welfare in Korea. The task for Korean Social Welfare can be analyzed critically into five categories. Firstly, the nation's sympathy and approval must be sought for a particular welfare system. Secondly, it is necessary to increase the people's level of awareness of welfare issues. Thirdly, it is necessary for policy-makers to be aware of the problems in the Korean welfare system, and to have professional knowledge and accomplishments, and the power of decision-making on social welfare policy. Fourthly, an effort is needed to increase the level of expenditure on welfare. As welfare finance primarily derives from the nation's taxes, it is important to carry out taxation through a fair system as acknowledged by the people. Fifthly, it is necessary to develop a Korean social welfare model. Korean welfare model development needs to solve the problem of the right to survival of the socially deprived class and the socially weak, and social welfare policy and social services must be developed as a priority so as to guarantee their minimum livelihood expenditure to improve their quality of life. A welfare policy that includes the minority in social solidarity, and an intelligent, mature welfare policy which fosters integration, equality and unity, and allows for
\end{abstract}

the continuous development of social welfare policy, must be the primary focus. In future, social welfare must be a pivotal policy of the government to enable it to recover its legitimacy and trust, and in implementing this there will be a greater sense of national unity and duty. Accordingly, I expect the Korean welfare model to be a driving force in the development of a multi-cultural society and in resolving the North-South division and confrontation and regional conflicts and divisions through regional solidarity.

Keywords Social Work, Social Welfare, Residual Welfare, Institutional Welfare, Neo-liberalistic Welfare, New Social Risks, Neo-liberalism, Globalism

\section{Introduction}

The beginning of social work and its formation differ in each society due to its unique historical and social background inherent to a society, so the beginning of social work in Korea is also categorically influenced by historical events.

How social work in Korea began and why the expression 'social work' is no longer used and has been replaced by 'social welfare' can be understood in the context of the social work development process in Korea, as the change of word usage can be viewed as a product of history that reflects its epoch and society. Up until around 1980, all the work in this field had been called 'social work', thereafter the terminology 'social welfare' was used, but there is no longer any differentiation between these two terms as the microscopic approach of social work on personal services and the macroscopic approach of social policy are jointly called 'social welfare'.

When compared with social welfare developments in advanced countries, social welfare in Korea has an unfortunate historical background. During 1910-1945 when advanced countries were working on the foundation of their welfare states, Korea was under Japanese occupation and all the systems in Korea were under the Japanese colonial authority. After independence, due to the power struggles 
and interests of the super powers, the Korean War broke out from which Korea suffered the painful historical experience of being a divided nation between North and South and until this day, the divided situation has produced ideological confrontations and suffering for the separated families. The restoration operations after the war, and the emergency aid schemes along with the orphan rescue operation initiated by the US were the beginning point of social work and the orphan rescue work has implanted the characteristics of social work in Korea.

In the 1970s following the Korean War in the 1950s and the aftermath in the $60 \mathrm{~s}$, social work which merely centered on emergency aid work and aid in care facilities could neither provide the quality of life nor solve the numerous and diverse problems in Korea. As personal problems were tied to the social structure and social problems inflict gravely on personal life, the microscopic approach of personal services had its limitations.

With the assassination of President Park Chung Hee in 1979 , when the society was in turmoil, another military regime of President Chun Doo Hwan appeared. As the Chun regime tried to earn the nation's support and its legitimacy by announcing their Administration policy named 'construction of a welfare society', the terminology of social welfare became more and more generalized. This seemed to represent general problem awareness in Korean society and from 1978 the terminology of social work and social worker previously used in universities changed to social welfare and social welfare worker respectively.

In addition, on 13th April 1985, the Korean Academy of Social Work formally changed its official title and the "Korean Academy of Social Welfare" was born and in accordance with the nation's wish for a welfare state, the organization was designed to achieve academic solutions for the welfare state. Furthermore the Korean Academy of Social Welfare was expected to overcome the characteristics of social welfare in Korea at that time and to further progress social welfare with the cooperative efforts of academics and leaders in different fields, especially politicians, administrators, and professionals. The foreign aid resulting from the Korean War together with the already operating American style social work had made up the main stream of social work in Korea until then, and throughout more than 40 years social welfare was clearly not autonomous which was not appropriate to solve Korean social demands. Moreover, rapid social change had eroded the existing community, which demanded a new social system. This research is to consolidate the details and characteristics of social work and social welfare development in Korea. Consequently, this paper focused how social work in Korea started, what are the patterns of social welfare development, and what are the prospects and problems of social welfare in Korea.

\section{Beginning of Social Work in Korea}

In the late 19c the word social work emerged in the West.
At that time, the work of Charity Organization Society was to assign needy individual candidates to a case and carry out home visits and aid activities by social case workers. In addition, the Settlement Movement appeared in the late 19c which developed into group action and social action. On the other hand, in 1895 in Korea, there was an article in 'Seo Yu Gyeon Mun (Notes from the West)' written by Yu Gil-Jun to introduce social work and social policy as exercised in the West which described the centers for the poor, hospitals, schools for mentally impaired, mental hospitals, homes for the blind, homes for the deaf and dumb, and the article also described the government's role in poverty relief organizations which operated old people's homes and community care houses. Moreover, during the Kye Hwa (civilization) era the 'Dongnim Sinmun (Newspaper for Independence)' published an introduction to western social work. (The 50th Anniversary, the Publication Committee of the Korean Academy of Social Welfare, 2007, p.34).

On the other hand, during the Japanese annexation, social work settled into a widely used vocabulary. As an example, Japanese Government-General Headquarters established the Social Department in 1921 and a Cho Seon Social Work Research Committee consisting of government officials. Articles published by the research committee revealed wide and diverse topics including poverty relief, leprosy, birth control, social solidarity responsibility and even a poverty relief committee system, and it indicates social work did not limit itself to simple charitable work or humane work rather it included interests in policy making on all kinds of social problems including poverty and disease (The 50th Anniversary, the Publication Committee of the Korean Academy of Social Welfare, 2007, p.34).

After the chaotic era following independence (1945), emergency aid work concentrating on refugee relief had commenced and during this maelstrom, social work education programs were installed at universities. People returning to Korea after independence and North Koreans coming down from the North were mostly refugees who needed emergency aid. Besides them, there were many indigenous destitute Koreans who had been leading impoverished lives under Japanese occupation. It was the responsibility of the US military government and the succeeding Korean government to help them. The US military government commenced its emergency aid work at the war victim aid policy level. As the nation had not yet established its own regulations, under the relief policies of Japan's Korea Relief Ordinance and the Welfare Memorandum of the US military government administration, US style social work was introduced to Korea by American social workers who came under the US military government office. The US government had deployed social workers in the US military since World War I, and a number of social workers worked in Korea for 3 years following 1945, operating in accordance with US military procedures. (The 50th Anniversary, the Publication Committee of the Korean Academy of Social Welfare, 2007. pp.35-36). 
During the US military government, US social workers realized that Korea needed a more organized systematic social service system rather than just emergency aid work and so in 1947 they opened the Christian social work department in Ehwa Women's university which was the first ever systematic specialized education in the form of evening lectures on social services.

The Korean war had a decisive influence for social work to develop into emergency relief and aid work in care facilities. After World War II, the Korean war was the first full scale conflict between East and West under the Cold War climate which claimed several hundred thousand casualties and several million war victims. Priority measures implemented were first for the war orphans, war widows, the homeless, and the injured around the aid centers. Clothing, food and housing were the priority at that time hence the social workers could be defined as a simple labor force rather than as social service professionals.

From Independence up to the US military government period, support for emergency aid was solely from the US through their huge aid to Korea, but after the Korean War, relief goods from foreign civil aid organizations started to make up an important part of the aid. Thus the situation heightened the need for systematic management and administration. To satisfy this need, in 1953, the Social Work Department was opened at Choong Ang Theology University and in 1956, the 'National social workers Training Centre' was opened to train social workers, even though it was not at university level, and the year after, 1957, the Korea Academy of Social Work was established.

In brief, it can be said that the social work period in Korea has had residual and selective welfare characteristics.

\section{Development of Social Work and Social Welfare in Korea}

With this background, social work in Korea is divided into a residual welfare period (introduction and settlement period: 1960-1979), an institutional welfare period (expansion period: 1980-1998), and a neo-liberalistic welfare period (development period: 1998-present).

The residual welfare period during the Park Chung Hee regime suppressed and controlled people's quality of life through industrialization, and the institutional welfare period during the Chun Doo Hwan rule, with its administrative policy under the slogan of 'construction of a welfare society', saw general social welfare take root. The neoliberal welfare era is the period of government intervention welfare derived from the strong feeling of the acute need for social welfare in Korea, after the IMF foreign currency crisis, along with the values of globalization.

Residual Welfare Period (1960-1979)

From independence in 1945 until 1960, the year before the May 16th military coup, the characteristics of social welfare consisted mainly of aid work during the US military government period (1945, Sept-1948, Aug), to overcome absolute poverty, and after the Korean War, emergency aid work for the separated families, war victims, and war orphans were the main target. After that, during the chaotic political conflict period of the Syngman Rhee Regime, the government tried to gain a supporting foundation for its political power by favoring an exclusive group of people such as government officials on the national level, and also aiding care facilities on the civilian level through charitable and relief work.

On May 16th, 1961 General Park Chung Hee's military authority which seized power in a coup, enforced strong political, economic, and overall social reformation through its authoritarian central government system. The goal of its national policy of 'independent economic construction' promoted an industrialization policy concentrating on economic growth to eliminate poverty and to become a prosperous nation, and it promoted export-led industrialization in light industry using cheap labor. Accordingly, despite the increase in the nation's earnings, the inequality in regional and industrial earnings brought serious social problems, and the desire for welfare was greatly increased due to poverty, disease, and unemployment. In spite of this social situation, it appeared that social welfare expenditure tended to decrease. The ratio of social welfare expenditure in the government budget indicated a declining tendency as the brief increase of $2.55 \%$ in 1963 compared to $0.95 \%$ in 1961 soon declined to $0.75 \%$ in 1972 , which showed the declining trend in social welfare expenditure allocation. (Ha Sang-Lak, 1989, p.97)

The Park Chung Hee regime stressed economic development as the most important task, advocating the policy of 'development first and distribution later', hence any concern for social welfare was pushed back. In the early 1960s, although the Park Chung Hee regime enacted 14 social-welfare related laws, including the Livelihood Protection Law (1961), the Industrial Injury Compensation Law (1963), and the Health Insurance Law (1963), the implementation of these laws was limited to the Civil Servants' Pension Law and the Soldiers' Pension Law, and the Disability Insurance Law. The enactment of these laws can be viewed as a strong government's purpose of expanding support groups for the legitimacy of its regime and to gain people's support that was vital for its industrialization.

The Industrial Injury Compensation Law was just a formality as the law at first was only applied to workplaces with more than 500 employees, and it did not reflect the reality of Korean industry, as most of Korean businesses consisted of small and medium sized enterprises. Since then the application scope was expanded; $40 \%$ of all workers were covered by the law in 1990, and currently almost all workers in small businesses are protected by the law. The Industrial Injury Compensation Law is mostly funded through employers' contributions. 
Table 1. Social Welfare-Related Laws of the Residual Welfare Period (1960-1979)

\begin{tabular}{|c|c|c|}
\hline Category & $\begin{array}{l}\text { 1960-1972: The } 3^{\text {rd }} \text { Republic } \\
\text { (Park Chung Hee) }\end{array}$ & $\begin{array}{l}\text { 1972-1979: The } 4^{\text {th }} \text { Republic } \\
\text { (Park Chung Hee) }\end{array}$ \\
\hline Public Assistance & $\begin{array}{l}\text { - The Rehabilitation Protection Law (1961) } \\
\text { - The Military Support Compensation Law (1961) } \\
\text { - The Livelihood Protection Law (1961) } \\
\text { - The Disaster Relief Law (1962) } \\
\text { - The Protection Law for National Heroes and } \\
\text { Defectors to South Korea (1962) }\end{array}$ & -Medical Protection Law (1977) \\
\hline Social Insurance & $\begin{array}{l}\text { - The Government Employee's Pension Law (1960) } \\
\text { - The Sailors Insurance Law (1962) } \\
\text { - The Soldiers Pension Law (1963) } \\
\text { - The Industrial Injury Insurance Law (1963) } \\
\text { - The Medical Insurance Law (1963) }\end{array}$ & $\begin{array}{l}\text { - National Welfare Pension Law (1973) } \\
\text { - Private School Teachers Insurance Law (1973) } \\
\text { - Amendment of Medical Insurance Law (1976) } \\
\text { - Government Employees and Private School Teachers Medical } \\
\text { Insurance Law (1977) }\end{array}$ \\
\hline Social services & $\begin{array}{l}\text { - The Orphans Adoption Special Case Law (1961) } \\
\text { - The Law on Preventing Acts of Prostitution (1961) } \\
\text { - The Law on Orphans Guardianship (1961) } \\
\text { - The Child Welfare Law (1961) } \\
\text { - The Child Welfare Work Law (1970) }\end{array}$ & $\begin{array}{l}\text {-The Mother-Child Health Law (1973) } \\
\text {-The Law of Special Cases in Adoption (1976) } \\
\text {-The Special Education Promotion Law (1977) } \\
\text {-The Special Protection Law for Vietnam War Veterans (1977) }\end{array}$ \\
\hline
\end{tabular}

The National Pension System was enacted in 1973, but due to the economic crisis at that time, it was not implemented until 1988, the Law on Social Security was enacted in 1963, but it did not present any concrete program until 1980.

In the 1970s, although 11 laws were enacted including the National Welfare Pension Law (1973) and the Medical Protection Law (1977), welfare-related laws during the Park Chung Hee regime were merely a formality and it is not an exaggeration to say that the laws were introduced to secure a support foundation for the government and for the legitimacy of its regime. During the 1970s, the support rate declined due to inflation and economic stagnation and the Park Chung Hee regime proclaimed 'Yu Shin (Reformation) Policy', as an emergency measure, feeling the nation's ideology of anti Communism had subsided as the Cold War system had weakened internationally. Park was determined to be a lifetime President, by maximizing Presidential power through his Emergency Measures by which he controlled workers rights, suspended the accountability of government administration, abolished the independence of the judiciary, and eliminated freedom of speech. However, the Park Chung Hee Dictatorship came to an end after 18 years following the democratization movement of academics, workers and students who united as one against the regime, and his assassination on 26th October 1979. The economic development policy during the Park regime supported export-led industrial growth policy with low wages. With the 1st and 2nd Five-Year Economic Development Plans, the Korean economy expanded and national earnings increased rapidly. Nevertheless, because of the low pay policy, conditions for poor workers could not improve and they were forced to make sacrifices.

At that time, Park Chung Hee who declared rivalry against North Korea, felt the limitations in the military armaments competition, hence the regime promoted the heavy chemical industry but he was faced with problems in finance supply that was necessary to set up large scale industries. In 1973, the regime then enacted 'the National Welfare Pension Law' for the general public such as workers, farmers and fishermen, the self-employed urbanites as a means of mobilizing the capital needed in developing a heavy chemical industry from the existing light-industry-centered industry, but it dissipated due to the strong resistance by the Opposition Party and the oil crisis. The National Welfare Pension law, which is currently causing social debate due to the exhaustion of its capital, had its origin not for the purpose of securing superannuation for the nation, but as a means to raise the necessary capital for industrialization and knowing the history provides a self-explanatory reason why this scheme has not yet to date been able to fulfill its purpose.

After independence through the chaotic period of the US military government and the Korean War in 1950, the residual welfare period had continued for 16 years from the Syngman Rhee regime in 1961 to the Park Chung Hee military regime in 1977. This period can be viewed, as the export-led industrialization strategy and growth-targeted policy period, and authoritarian politics continued without a labor movement or a leftist political party, the sacrifice by workers and farmers was enormous during the policy of low wages and low grain prices. No one except government officials and soldiers could receive any welfare benefit and the backwardness of the welfare system, compared with the economic growth, could not be avoided.

The preparation of formal legal framework in the 1960s, created a national pension scheme for the general public, excluding soldiers and government officials, and the Medical Insurance Law (1976) and the Medical Protection Law (1977) were revised in late 70s. However, compared to Western societies who faced crises as welfare states after falling from the height of prosperity, Korea was going forward laboriously little by little in its own situation without any relevance to the tide of change in the western welfare states.

Social welfare in this period, as a whole ended up being such in name and form only, containing residual and selective characteristics and social welfare had its limitations 
in carrying out its original role as a consequence of being subordinated to politics.

Beginning of the institutional welfare period (1980-1998)

At the end of the 1970s, with the implementation of the Medical Insurance Law (1977) and the Medical Protection Law (1977), the basic framework had been laid for all the nation to be secured for their health and this marked the opening of the national insurance period. Therefore, the institutional welfare period fundamentally had begun with the National Pension Law (1986) and the Employment Insurance Law (1994) and from then on until December 1997 when the IMF foreign currency crisis threatened Korea, it is analyzed as Korea's systematic universal welfare period.

The Chun Doo Hwan Regime (1980-1987)

During 1980-1997 the situation of this period when institutional welfare was gradually taking root, the Fifth Republic was born under the merciless military grip of General Chun Doo Hwan pushing back the nation's hopes for democracy held for a brief moment in the 1980s. As with Park Chung Hee, the Chun Doo Hwan regime that came to power by means of a coup, needed to gain its legitimacy. With this background, the government managed the welfare field by revising and expanding welfare related laws, emphasizing the realization of a just society and the construction of a welfare state. Especially, the Chun Doo Hwan government legislated and amended the Aged Welfare Law (1981, 1984), the Mentally and Physically Disabled Welfare Law (1981, 1984), the Child Welfare Law (1981, 1984) by focusing on Medical Insurance and Public Assistance Programs. These laws became the legal root and branch of the Korean Social Welfare Services, furthermore a comprehensive social welfare policy was formed by introducing the national pension system $(1986,1988)$ and the minimum wage system $(1986,1988)$.

1981 saw a big change in the social welfare system as the Child Welfare Law was revised from the Child Benefit Law and the Livelihood Protection Law was also largely revised, and so forth. While the Child Benefit Law revised in 1961 limited its beneficiaries to 'Children Under 18 requiring Protection', the Child Welfare Law revised in 1981 declared its beneficiaries to all children under 18, which showed its propensity for universal welfare in its title. Even though the contents are not sufficient so far, the institutional period is the era when the term welfare or social welfare began to spread widely among the general public.

After late mid 1982, labor movements and democratic liberalization brought the chance for progress to the welfare system. However, the construction of a welfare state by the Chun Doo Hwan government progressed rather gradually and passively, and in the mid 1980s, as the resistance of workers became increasingly strong, the government started to prepare a strategy to pacify the labor movements by enacting a minimum wage system, three major welfare policies, i.e. the three major bills in 1986, a national pension scheme and the expansion of medical insurance to the farming and fishing communities, along with the Equal Employment for Both Sexes law. Therefore, these laws had strong political characteristics as they were enacted not for the necessity of the nation but for political means to escape its social crises.

The 5th Republic proclaimed its four administrative targets i.e. the Settlement of Democracy, Construction of a Welfare State, Establishment of a Just Society, Educational Reforms and Cultural Promotions, and several social welfare-related laws were enacted and revised as the platform of the construction of a welfare state. The Chun Doo Hwan government was more or less progressive in foreign relations, in its relations with North Korea, in the sports and diplomatic fields, and in the economic sector, the regime yielded positive achievements owing to the "three low boom' period featuring a stable cost of living, export growth and a trade surplus.

On the other hand, internally the regime suppressed freedom, oppressed democratization movements, violated human rights exhibiting the pattern of a military dictatorship that resulted in the obstruction of political development.

The Roh Tae Woo Regime (1988-1992)

President Roh Tae Woo, succeeding President Chun Doo Hwan, revised existing laws and introduced new social related laws such as Equal Employment for Both Sexes (1987), the Mother-Child Welfare Law (1989), the Industrial Injury Compensation Law (revision in 1989, addition of governmental contributions), and the Promoting Employment of the Disabled law (1990). In this way progress had been made by including medical insurance for self-employed urbanites (1989) and the farming and fishing communities (1999). In addition, the delivery of a national pension scheme and minimum wage system in 1988 provided an opportunity to enhance the quality of the social welfare system.

In Korean modern political history and Korean social welfare, there was much significant progress in 1987. In 1988, at the beginning of the 6th Republic, a restrictive form of a democracy emerged with the participation of many political parties, transferring the country into a democratic nation after the democratization struggle of 1986. The conversion to a restrictive democracy accompanied not only the democratization of the political strata but the democratization of social and economic strata at the same time. In 1987, the 13th presidential election provided an opportunity to establish a peaceful transfer of power for the first time in the political history of Korea. This election was carried out in a direct presidential election and from the beginning its legitimacy was acknowledged by the opposition party.

On the social welfare side, since 1987 a series of governmental and capital welfare provisions were made exclusively for the working class. The core of this explosive expansion of welfare is represented by the implementation of the National Pension Scheme, a nationwide implementation of the Medical Insurance System and the delivery of Minimum Wage system. The' National Pension Scheme' law was enacted in August and October 1987 in accordance with the establishment of the Implementation Law and 
Implementation Regulations, after being enacted in December 1986, and from Jan 1st 1988, the Pension for the Elderly, the Disabled Pension, Widow(er)s' Pension, and "One Lump Sum Refund" was implemented. After the Medical Insurance system was revised in 1976, its beneficiaries were expanded from a workplace with more than 300 workers in 1977, to a workplace with more than 100 workers from January 1981, and to a workplace with more than 16 workers in April 1986 according to the Implementation Obligation Regulations for all workplaces. Finally, the revision in December 1987 expanded the law to include all workplaces with more than 5 permanent workers. Furthermore, in 1988 the implementation of the Farmers and Fishermen Medical Insurance and the expanded implementation of Medical Insurance to urbanites from July 1989 brought the era of Medical Insurance for the entire citizenry.

In addition, the 'minimum wage law' enacted in December 1986 together with Industrial Injury Compensation Law, which are the most important systems to protect workers' working conditions by enacting the Implementation Law and the Implementation Regulations. Accordingly, the Minimum Wage Law and the 'National Pension Law' were implemented from 1 January 1988. By introducing this universal social welfare system, Korea was at a pivotal point in its progression towards a welfare state.

From 1987 social welfare in Korea developed further through the implementation of a national pension scheme, the expansion of medical insurance beneficiaries, the minimum wage system, and also by announcing a plan for the supply of 250,000 houses for workers that was implemented in 1990. The Promotion of Employment Law for the Disabled (January, 1990), the Young Child Care Law and the Enforcement Ordinance (January, 1991), and Senior Citizen Employment Promotion Law (December, 1991) were enacted to promote employment for disadvantaged workers such as the disabled, women, and senior citizens.

The welfare expenditure of the country increased distinctly due to the expansion and implementation of the social welfare policy. Particularly, welfare expenditure was at its highest level, except for the welfare expenditures in 1960 during the Syngman Rhee regime for war-related aid efforts, and the welfare expenditures in 2000 for the large-scale welfare work needed after the economic crash, arising from the foreign exchange crisis in 1997. The general account budget of the Ministry of Health and Society remained at the $2 \%$ level prior to the June struggle in 1986 . Since then it increased steadily reaching 5.02\% in 1990, the highest ever since 1960. (The 50th Anniversary, Publication Committee of the Korean Academy of Social Welfare, 2007, p.126).

From the $80 \mathrm{~s}$, the nation's desire for the construction of a welfare state got stronger as self problem consciousness strengthened. The Government tried to find out theoretically and practically what the methods were for solving the problems, what the nation's demands were, and what the shortcomings of the existing systems in society were. The Roh Tae Woo regime enacted a large number of social welfare-related laws at government level to satisfy the nation's desire for democratization and to pacify workers after the Workers Strike and prepared a legal foundation to meet its current needs by partially revising existing laws. Particularly, as the 'Minimum Wage System' and the 'National Pension', implemented from 1st January 1988, were historically meaningful as representing the beginning of institutional welfare.

During this period, as the interest of regional welfare increased along with the revival of regional self-governing systems, Social Welfare Centers were constructed and professional social welfare worker systems were in place to reflect the desire of local residents and help the poor. According to the Rental Housing Construction Promotion Law (1984) enacted during the Chun Doo Hwan regime, the government made efforts to provide minimum living conditions by constructing Permanent Rental Housing (1989).

The Kim Young Sam Moon Min (non-Military) Government (1988-1992)

President Kim Young Sam is significant as he is the first Korean president with no military background to be elected through the democratic process. The Kim Young Sam Administration put forth a slogan of 'building a new Korea' and included in its governing strategy redistribution and industrial development that was stable and in tune with globalization, and liberalization. As employment Insurance and the pension system for farmers and fishermen were implemented in July 1995, all the social security systems that included public assistance, social insurance, and social welfare services from 1961 to 1995 , were all complete in form. What is important in this process is that Korea made enormous efforts to overcome its social policy that was residual, supplemental, and peripheral. In addition through the great democratization struggle of 1987, the direct presidential election was the first peaceful transfer of power in Korean political history and it gained its legitimacy by being recognized by the opposition party for the first time.

As [Table 2] below indicates, during the 6th Republic, due to labor movements and the social environmental atmosphere, as well as the social insurance system, many laws in the social services field were enacted. The following laws were all enacted in quick succession; the Mother-Child Welfare Law (1989), Protection and Observation Law (1989), the Welfare Law for the Disabled (1989), the Promoting Employment for the Disabled law (1989), the Young Child Care Law (1991), and the Promoting Employment of Senior Citizens law (1991) 
Table 2. The Social Welfare-Related Laws of the Institutional Welfare Period (1980-1997)

\begin{tabular}{|c|c|c|c|}
\hline & $\begin{array}{l}\text { 1980-1987 } \\
\text { The } 5^{\text {th }} \text { Republic } \\
\text { (Chun Doo Hwan) }\end{array}$ & $\begin{array}{l}\text { 1988-1992 } \\
\text { The } 6^{\text {th }} \text { Republic } \\
\text { (Roh Tae Woo) }\end{array}$ & $\begin{array}{l}\text { 1993-1997 } \\
\text { The Moon Min(non-Military) Government } \\
\text { (Kim Young Sam) }\end{array}$ \\
\hline $\begin{array}{l}\text { Public } \\
\text { Assistance }\end{array}$ & $\begin{array}{l}\text { - A complete revision of the Livelihood } \\
\text { Protection Law:(1982.12) } \\
\text { - The Honorable Treatment Law for Person of } \\
\text { Merit } \\
\text { - The revision of the Rehabilitation Protect } \\
\text { Law (1986) }\end{array}$ & $\begin{array}{l}\text { - The implementation of Social Welfare Professional } \\
\text { Personnel system } \\
\text {-Generalization of the Construction of Welfare } \\
\text { Centers Constructions }\end{array}$ & $\begin{array}{l}\text {-The War Comfort Women Support Law (1993) } \\
\text { - The North Korean Refugee Protection and Settlement Law (1997) }\end{array}$ \\
\hline $\begin{array}{l}\text { Social } \\
\text { Insurance }\end{array}$ & $\begin{array}{l}\text { - The revision of the National Pension Law } \\
\text { (1986) } \\
\text { - The revision of the Medical Insurance Law } \\
\text { (1986) }\end{array}$ & $\begin{array}{l}\text {-The Implementation of National Pension (1988) } \\
\text { - The Implementation of Medical Insurance for } \\
\text { Farming and Fishing communities. } \\
\text { - The Implementation of Medical Insurance in Cities } \\
\text { (July, 1989) }\end{array}$ & $\begin{array}{l}\text { - The Employment Insurance Law (1994) } \\
\text { - The Implementation of Farmers and Fishermen's Pension (July, 1995) } \\
\text { - The National Medical Insurance Law (December, 1997) } \\
\text {-Integration of Medical Insurance in Urban and Rural Area, Government } \\
\text { Employee and Teachers(October, } 1998 \text { Implementation) }\end{array}$ \\
\hline Social Services & $\begin{array}{l}\text {-The Social Welfare Work Fund Law (1980) } \\
\text { - The Child Welfare Law (1981) } \\
\text { - The Welfare for the Physically and Mentally } \\
\text { Disabled Law (1981) } \\
\text { - The Senior Citizens Welfare Law (1981) } \\
\text { The Equal Employment for Both Sexes Law } \\
\text { (1987) }\end{array}$ & $\begin{array}{l}\text { - The Mother-Child Welfare Law (1989) } \\
\text { - The Protection and Observation Law (1989) } \\
\text { - The Welfare for the Disabled Law (1989) } \\
\text { - The Young Child Care Law (1991) } \\
\text { - The Promotion of Employment for Senior Citizens } \\
\text { Law (1991) }\end{array}$ & $\begin{array}{l}\text {-The Mother Child Health Law (1994) } \\
\text {-The Mental Health Law (1995) } \\
\text { - Sexual Violence Punishment and Victim Protection Law (1994) } \\
\text { - The Youth Protection Law (1997) } \\
\text { - The Social Welfare Public Fund raising Law (1997) } \\
\text { - The Revision of the Welfare for the Disabled Law (1997) } \\
\text { - The Revision of Social Welfare Legislation Law (1997) } \\
\text { - The Prevention of Domestic Violence and Victim Protection Law (1997) } \\
\text {-The Convenience Promotion for the Disabled and the Elderly Law (1997) }\end{array}$ \\
\hline $\begin{array}{l}\text { Other related } \\
\text { Laws }\end{array}$ & $\begin{array}{l}\text {-The Rental Housing Construction } \\
\text { Promotion Law (1984) } \\
\text { - The Minimum Wage Law (December, } \\
\text { 1986) }\end{array}$ & $\begin{array}{l}\text {-The Implementation of the Minimum Wage System } \\
\text { (1988) } \\
\text { - The Permanent Rental Housing Construction (1989) }\end{array}$ & $\begin{array}{l}\text {-The Rental Housing Law (1994) } \\
\text {-The Social Security Basic Law (1995) } \\
\text { - The Equal Employment for Both Sexes Law (1995) } \\
\text {-The Women Development Basic Law (1995) } \\
\text {-The Youth Basic Law (1995) } \\
\text {-The Consumers Life Cooperation Union Law (1997) }\end{array}$ \\
\hline
\end{tabular}


The Kim Young Sam government particularly tried to expunge political corruption and sever political and economic adhesion, but unfortunately it all failed due to the cozy relations between politics and business of Hanbo Group, illegal financial dealings in the election campaign by his son. Korea also established a new Five-year Economic Development Plan (1993-1997), however it faced serious economic crises due to insufficient preparation for the changes brought about by globalization. The social background of the expansion of its institutional welfare as well as the rise of the nation's quality of life as pre-conditional requirements for the entry to the OECD is not unrelated to the enactment of relevant laws to protect the socially weak.

In addition, the Kim Young Sam regime designed the Korean welfare model ${ }^{1)}$ for the first time as productive welfare and its brief summary of the Korean welfare model characterized the importance of economy and growth, independent responsibilities for the family, the emergence of civil groups, enterprises and religious groups as a welfare provision identity which has a strong neo-liberalistic characteristic highlighting the need for self-support by individuals.

\section{The Neo-liberalistic Welfare Period (1998-the Present)}

\section{The IMF Economic Crisis and Welfare in the neo-liberalistic} period

In Korea, since 1980, the progress of political democratization influenced the nation's desire to express its rights and a chain of democratic processes became a driving force for the development of a Social Welfare system. However, the economic crisis in December 1997 pushed the whole nation into an economic depression. While the nation's desire for welfare sharply increased, Korea experienced a political dilemma in this conflicting situation as economic pressure grew even stronger due to increased international competition. The beginning of economic intervention and controls by the IMF exposed the limitations and shortcomings of the Korean Social Welfare Policy, especially its employment policy. Due to insufficient social welfare programs and lack of experience in welfare, as well as the increasing pressure of economic globalization, social welfare programs in Korea faced increasing difficulties.

Accordingly, Korea, facing serious problems, was thrown into two conflicting situations. Firstly, whether Korea could survive in the global economy while embracing globalization without losing its competitive power and secondly, whether Korea could construct a welfare state implementing fair

\footnotetext{
1) Basic concept of productive welfare is as follows; a harmony of growth and welfare and to supplement the shortcomings of the western welfare system with Korean social morals and customs by helping to harmonize family, relatives, and neighbors. Strengthen self-support with productive, preventative and pluralistic welfare and finally to pursue material and mental happiness (National Welfare Planning Board, 1995)
}

distribution in its globalization process.

The economic crisis towards the end of 1997 derived from malfunctions in the political system resulting in a failure of the government economic policy, the lack of a business code of conduct, and the non-existence of a civil sprit based on a mature democracy and of the obligations of duty. Even though democracy developed continuously in Korea, the cozy relation between politics and economics still exists in large businesses. The economic crisis in 1997, by exposing serious shortcomings in the welfare policy, and the consequent development of other serious problems, provided a turning point and an opportunity. This historical lesson forced Korea to accept a status of a 'not developed' country. Unlike other developed countries, welfare policy in Korea was being expanded during the process of globalization. The important motives for this were the strong awareness of the nation's under developed status in the social welfare field among OECD member countries and the importance of the expansion of a social safety net to compete successfully in a liberal and competitive economy. Therefore, a government that neglects its welfare duty and follows the world trend of neo-liberalism has no excuse for not winning over its people.

After the foreign exchange crisis, the weakness of Korea's employment security system was deeply felt and the government believed that its vital task was to focus all its power on aid for the unemployed and the homeless. For the following almost two years, the government promoted public works and provided assistance and subsidies to needy people. Employment training lectures which taught new skills were established and accommodation and protection facilities for the homeless were prepared. Although Korea put in a lot of effort to re-regulate its economy, it could not escape the economic crisis brought about by liberalization and globalization.

Korea has recognized, since the exchange crisis that the core of a welfare policy lies in income security programs. The driving force for competitive and effective economic promotion lies in employment training, the creation of new opportunities in employment, a social security system on a solid financial foundation, and a retirement pension system. To enlarge work-related programs and to solve the inequality of the management of job training education and opportunities, the government must have a strong will to implement the policies. The flow of Korean welfare is similar to the welfare route of Europe. The high social value of social ties and income security are very important in neo-liberalism. Even though the social background of Korea and the social democratic model of Europe are not similar in any form, social security in Korea is faced with a social situation that must follow the European model emphasizing social security and family welfare.

Social investment for welfare reformation is only possible under economic and political democratization. Therefore, to escape from the Korean dilemma people have to participate voluntarily in the capitalist market economy and expand their market participation opportunities. This is not merely to support social misfits through a welfare safety net, but it 
needs to be preconditioned to help with education and skills that allows them to satisfy their desire and make them independent.

The ideological background of productive welfare in Korea is the combination of neo-liberalism and a third way. However, as a third way might offer only neo-liberalism to Korea without the foundation of social democracy, it is vital to implement a suitable welfare policy for Korea after multilateral research and then gradual implementation. Even countries in Northern Europe, which have traditionally had welfare states, demonstrate Flexicurity (Flexibility+Security) that emphasizes the need for flexibility of social security as a pre-condition. This is something that we can lern.

The Kim Dae-jung 'People's Government' (1998-2002) and The Roh Moo-Hyun 'Participation Government' (2002-2008)

Despite the fact that the Kim Dae-jung regime (1998-2002) was criticized for being neo-liberalistic and authoritarian in its economic policy, the regime tried to break and overcome economic difficulties and it can be seen to have gradually expanded public assistance programs for the general welfare of its nation.

The participation welfare of the Roh Moo-hyun regime has been progressing from 2002 to 2008 . The Roh Moo-hyun regime, under the administrative management of a continuing democratization process, the participation of the nation, and anti-authoritarianism, has been trying to establish a balanced society in a participatory democracy. However, due to failure of getting national consensus of the abolition of the national security law, the past accountability examination law, and the private school law, the expected result was not achieved, and since 2005, the regime focused on economic and public livelihood problems rather than democracy reformation. For instance, the FTA negotiations, new poverty, and the solution of social polarization appeared as important administrative tasks, and the social problems of the population such as the low birth rate and the ageing society became threatening factors to shake the whole welfare system.

Participatory welfare can be seen to succeed the welfare system of the Kim Dae-jung regime. Unlike productive welfare, being created to overcome the economic crisis, participatory welfare has active characteristics to reflect the nation's welfare desire in the changing social environment. As indicated in the following table, the contents of the policy are related mostly to social services that have a specific desire to enhance the lives of individual groups.

As the Kim Dae-jung and Roh Moo-hyun regimes following the Roh Tae-woo regime show, many social services related laws were enacted. This developed smoothly by converging the nation's desire along with progression of the democratization process. In particular, to solve the problem of the low birth rate, women welfare policy and birth promotion policy were imminent tasks to be implemented and this was effected with the initiation of the Women and Family Department.

A central part of participatory welfare can be poverty support, and low birth rate and ageing related policies. The participatory welfare Five-year Plan (January, 2004), emphasizing people's participation and government responsibility at the same time, comprises 'Hope for Korea 21 ' established to combat social polarization (September, 2005), the National Health Promotion Comprehensive Plan implemented to amend and supplement the National Lifetime Health Management system (December, 2005), 'Sae Ro Maji Plan 2010 (2006-2010) i.e. Life Long Plan 2010 (July, 2006)', a basic plan for the low birth rate and aging society. 'Sae Ssak Plan i.e. New Buds Plan (July, 2007)' to expand community and diversity to elevate the standard of child care services, and 'Together Hope for Korea vision 2030' (August, 2006) for a national future strategy. In addition regional welfare work was strengthened allowing regional autonomous rights, it re-implemented the social welfare work law (2003) and established regional social welfare plans which develop regional characteristics and reflect the welfare needs of local residents. 
Table 3. The Welfare System of the Neo-liberalistic Welfare System (1998-2012)

\begin{tabular}{|c|c|c|c|}
\hline & $\begin{array}{l}\text { 1998-2002: } \\
\text { People's government } \\
\text { (Kim Dae-jung) }\end{array}$ & $\begin{array}{l}\text { 2003-2007 } \\
\text { Participation government } \\
\text { (Roh Moo-hyun) }\end{array}$ & $\begin{array}{l}\text { 2008-2012 } \\
\text { Lee Byung-park } \\
\text { government }\end{array}$ \\
\hline Public services & $\begin{array}{l}\text { - Nation Basic Livelihood Security Law (2000) } \\
\text { •Unemployment Policy, Public Social Expansion Income } \\
\text { Support }\end{array}$ & $\begin{array}{l}\text {-Income Support for the Poor } \\
\text { - Youth Unemployment and Facility Support for the } \\
\text { Disabled }\end{array}$ & $\begin{array}{l}\text {-Expansion of civil-work job for poor people } \\
\text {-Welfare based on Needed people }\end{array}$ \\
\hline $\begin{array}{l}\text { Social } \\
\text { insurances }\end{array}$ & $\begin{array}{l}\text { - Self-employed Urbanites Pension (1999) } \\
\text { - Health Insurance, Job Integration (1998) } \\
\text { - Medicine Division (1999), Industrial Injury Expansion } \\
\text { (2000) } \\
\text {-Employment Insurance Expansion (1998) } \\
\text { - Labor Market Policy (1998) } \\
\text { - Social Welfare Five-year Development Plan (1998) }\end{array}$ & $\begin{array}{l}\text {-Pension Reform on Debate } \\
\text { - Health Insurance Beneficiary Expansion (2003-2005) }\end{array}$ & $\begin{array}{l}\text {-Long-term CareInsurance(2008) } \\
\text { - Basic Old-age Pension(2008) }\end{array}$ \\
\hline Social services & $\begin{array}{l}\text { - Motherhood Protection Law (2001) } \\
\text { - Senior Citizens Pension (1998) } \\
\text { - Elderly Health Promotion General Policy (2002) } \\
\text { - Ante and Post Natal Leave (1999) } \\
\text { - Paid Sick Leave (2001) } \\
\text { - Domestic Violence Prevention Law (1998) } \\
\text { - Single Parent-Child Welfare Law (1998) } \\
\text { - Disabled Welfare Five-Year Plan (1998) } \\
\text { - Disabled Welfare Law Amendment (1999) } \\
\text { - Safety Net Expansion for the Homeless and Unemployed }\end{array}$ & $\begin{array}{l}\text { - Public Service Medical Expansion (2005) } \\
\text { - Healthy Family Basic Law (2003) } \\
\text {-Elderly Medical Care Insurance (2005) } \\
\text {-Increase of Elderly Respect Money (2005) } \\
\text { - Birth Promotion Fund (2004) } \\
\text { - Women Welfare Policy (2003-2005) } \\
\text { - Bankrupt Rescue (2004) } \\
\text { - Enactment of Young Child Care Law (2004) } \\
\text {-Disabled Welfare Five-year Plan (2003) } \\
\text {-Disabled Benefit expansion, Homeless Counseling and } \\
\text { Protection Center (2003) } \\
\text { - Amendment of Social Welfare Work Law (2003) } \\
\end{array}$ & $\begin{array}{l}\text { - Full Support of Nursery Fee gradually till } 2011 \text { for low \& } \\
\text { middle class } \\
\text { •Pension System forDisabled(2010) } \\
\text {-Improvement of Delivery System for low income people }\end{array}$ \\
\hline Others & & $\begin{array}{l}\text { - Participatory Welfare Five-Year Plan } \\
\text { - Hope Korea } 21 \\
\text { - National Health Promotion Comprehensive Plan } \\
\text { - Sae Ro Maji Plan (Life Long Plan) } \\
\text { - Sae Ssak Plan (New Buds Plan) } \\
\text { - Hope Korea Vision } 2030\end{array}$ & $\begin{array}{l}\text {-Active Welfare } \\
\text {-Expansion of Housing Provision }\end{array}$ \\
\hline
\end{tabular}


Table 4. The Governmental Welfare Characteristics and Contents

\begin{tabular}{|c|c|c|}
\hline Government & Periodical Characteristics & Contents \\
\hline $\begin{array}{l}\text { Military Regime } \\
(1961-1963)\end{array}$ & The Large Scale Social Welfare Enactment Era & -Interest in Social Welfare as a political tool for a power transfer \\
\hline $\begin{array}{l}\text { The Park Chung Hee Regime } \\
(1963-1979)\end{array}$ & The Social Welfare Stagnation Era & $\begin{array}{l}\text {-Efforts on economic growth and acquiring legitimacy of its regime } \\
\text { - Non-existence of awareness of the need for a social welfare system }\end{array}$ \\
\hline $\begin{array}{l}\text { The Chun Doo Hwan Regime } \\
(1980-1987)\end{array}$ & Establishment of the Formal Welfare Government & $\begin{array}{l}\text {-Augmentation of welfare budget } \\
\text { - Amendments and Expansions of welfare related laws } \\
\text { - Passive welfare development as part of social control and a head start strategy }\end{array}$ \\
\hline $\begin{array}{l}\text { The Roh Tae Woo Regime } \\
(1988-1993)\end{array}$ & The Formal Democracy and Welfare Explosion Era & $\begin{array}{l}\text {-Welfare system for the working class: } \\
\text { implementation of National Pension system, a nation-wide Medical Insurance system, and } \\
\text { Minimum wage system (supplement of previous law and introduction of new laws) } \\
\text {-Impediment in social welfare development deriving from the changes of political } \\
\text { environment }\end{array}$ \\
\hline $\begin{array}{l}\text { Kim Young Sam } \\
\text { The Moon Min Government } \\
(1993-1998)\end{array}$ & Social Welfare Development Stagnation Period & $\begin{array}{l}\text {-Importance on economic activation, and reduced budgets in the social security and health } \\
\& \text { welfare departments } \\
\text { - Premise of the concept of a residual social welfare principle as a Korean welfare model. }\end{array}$ \\
\hline $\begin{array}{l}\text { Kim Dae Jung } \\
\text { The People's Government } \\
(1998-2003)\end{array}$ & The Social Welfare Reformation Era & $\begin{array}{l}\text { - Integration and expansive implementation of social insurance } \\
\text { - The National Basic Livelihood security law enacted by changing the Livelihood } \\
\text { Protection Law } \\
\text { - Reinforcement of universality of the concepts of Productive welfare, and social rights }\end{array}$ \\
\hline $\begin{array}{l}\text { Roh Moo Hyun } \\
\text { The Participation Government } \\
\text { (2003-2008) }\end{array}$ & The Social Welfare Regional Decentralization Era & $\begin{array}{l}\text { - A participatory welfare: a welfare policy for independent, self-supporting democratic } \\
\text { citizens } \\
\text {-De-centralization, regional welfare autonomy } \\
\text {-Problem solving in polarization } \\
\text {-Expansion of social services }\end{array}$ \\
\hline Lee Myung Park Government(2008-2013) & $\begin{array}{l}\text { Market centered } \\
\text { Neo-Liberal welfare Era }\end{array}$ & $\begin{array}{l}\text {-Active Welfare } \\
\text {-Economic Activation } \\
\text { - Business friendly labor Policies } \\
\text { - Small Government }\end{array}$ \\
\hline
\end{tabular}


At the same time, the regime requires new policies to meet the needs of a multi-cultural society with the rapidly increasing influx of marriage-immigrant women, North Korean refugees, and immigrant workers. The Roh Moo-hyun regime, a participation government, setting sail in February 2003, is building a welfare policy for the people to have independent ability as a democratic nation, and stresses unemployment related labor welfare and national basic livelihood security systems. During The Kim Dae-jung and Roh Moo-hyun regimes, universal and institutional welfare expanded and diverse welfare work was implemented, reflecting the will of the nation. Nevertheless, as advancing neo-liberalistic globalization created economic difficulty for the people, and an increase in the number of poverty-stricken workers, a task was at hand to solve unemployment, contractual work problems, and polarization. When Lee Myung-Park was elected in Dec. 2007, it was the reason of financial crisis. He promised to solve the economic problems and put business-friendly Policies, but it was never so easy, that most people were disappointed with his unsuitable prescription at the end. His neo-liberal approaches were not the right solution in Korea, most corners became worse than before. The following [Table 4] shows each governmental welfare characteristics and contents.

\section{Emergence of New Social Risks}

\section{Neo-liberalism and Globalization}

With the development of science, transportation, and communication technologies, globalization brought the phenomena of global production, consumption and distribution, which used to be limited within the borders of its own country, and of escaping the capital crisis by overcoming its limitations through individual freedom and market self control.

As the world capital accumulation process indicated, from 1980 to 1990 , the world expanded through the money market and the industrialized nations' competition to overcome their economic crises became fierce. To maximize its interest in the world market and to predominate, businesses went abroad to take advantage of the favorable market conditions of low labor costs in under-developed regions. In order to transport capital and products freely, regional underdeveloped countries were asked to abolish trade obstacles and to relax government regulations. Accordingly, the world economy was increasingly reconstructed a neo-liberalistic stream of liberalization, the abolition of regulations, and privatization.

Korea emerged, through the globalization process on the basis of low labor costs as one of the four Asian Tigers along with Singapore, Taiwan and Hong Kong, and in the beginning, it benefited from neo-liberalism and globalization. After the 1980s, despite the fact that democratization had been a positive foundation for Korean development, with unsolved political and economic problems, Korea faced the IMF foreign currency crisis with a politically non functioning government, a failure of economic policy, the cozy relations between politics and business, the loss and abuse of the business code of conduct, and a general lack of awareness by the people of what was happening. Following the 1997 currency crisis, Korea seriously felt the need for income security programs and basic livelihood security to embrace the neo-liberalism tide. Job training and creation of work places, the social security system, and the pension system became the important and urgent national priority rather than the economically efficient neo-liberalism and globalization.

More worrying than the insecurity arising from the neo-liberalistic world economy and financial capital system, was to accept the world economic system derived from industrialized nations and to adapt to the neo-liberalism hierarchical system without any reservation. Globalization can be either beneficial or harmful depending on how effectively each country adjusts to globalization in its own interests. As shown from research ${ }^{2}$, globalization does not appear evenly, in all countries, and there are particular differences between industrialized nations and developing countries. (George and Wilding. 2002, pp.103-213, Kim Young-Hwa, 2006, pp.13-15)

By realizing how different the experiences of globalization are in each society, we realize how closely linked relations are between the market and the government, therefore globalization must be well managed rather than simply accepting and adjusting to it (Kim Young-Hwa, 2006, p.9) ${ }^{3)}$. To stabilize national employment and to protect workers against the destructive elements of globalization, more emphasis must be placed on the needs of a nation with more priority given to the construction of a safety net, improving social security provisions, an active job education policy and a labor market policy. (Kim Young-Hwa, 2006, p.8).

\section{Contractual Workers}

In Korea, the percentage of contractual workers that increased explosively after the IMF economic crisis in 1997 , today, after a decade, are not decreasing; rather they show an increasing tendency. In 2006, comparing figures for men and women, $67.7 \%$, reaching almost $70 \%$ amongst women and $46 \%$ amongst men were contractual workers. In the case of women, the ratio being much higher than that of men can be said to put women in a dire situation compared to men in the labor market in Korea.

As a new social risk, the problems of contractual work, due to having no access to basic livelihood security and the benefits of the welfare system, possess critical characteristics $^{4)}$ as it creates a destitute living standard and

\footnotetext{
2) A main example is George and Wilding, 2002, Globalization \& Human Welfare, Palgrave

3) A hint of a new nationalistic strategy can be seen here.

4) The Statistics Bureau announced the result of "the Economically Active Population Supplement Survey (types of work, unpaid work)" on Oct. $26^{\text {th }} 2007$. Over the past 4 years, the number of contractual workers increased by 7,000 to a total of 1,090,000 persons and last year there was a more than $4.5 \%$ increase in contractual workers and a more than $2.9 \%$ increase in permanent workers.
} 
an exposure to social risk that are linked to poverty and social exclusion.

The flexibility required by globalization enables businesses to employ and hire workers easily, and due to the flexible work policy, contractual workers to increase on a large scale. In addition, government target of 300,000 working places and 60,000 working places for women indicate a rather pessimistic approach. However, the type of employment increases the number of 'low income - manual work' positions while positions in manufacturing work decrease. Moreover, manual employment tends to increase continuously, and for the aged it shows sharp increases. Temporary, daily, and hourly work at the low-income level also increases. Employment figures for temporary and daily workers continuously grow as the figures of 5,400,000 in $1995,6,960,000$ in 2000, and 7,340,000 in 2006 show. (Dong A Daily Newspaper, Aug $3^{\text {rd }}:$ P10). Without taking account of this current situation, the contractual discrimination amendment system implemented from 1 July 2007 enabled many enterprises in financial crisis to transfer non-permanent workers to the manual labor and low income service sectors and created a large number of non-contractual workers, which had the side effect of lowering standards of work and income levels.

\section{Working Poor (New Poverty) Escalation and Polarization}

With the change in the economic environment and the development of transport, communication and industrial technology in the 1970s, the labor market structure gradually transformed into a post-Fordism system. Market restructuring derived from the change in the labor market and labor flexibility increased employment instability and the overall instability of laborers' livelihoods, and in 1990, the number of contractual workers increased. The appearance of a large number of contractual workers came to be known as 'working poor' and the concept of 'new poverty', which is different from traditional poverty, appeared. This means that although working, they could not escape poverty and they formed a new social class. The working poor class differs in each country, and scholars vary in their definitions, but the Health and Social Research Institute defined it as "households with $60 \%$ of the national average income". The working poor are defined as the "new poverty' recently, but 'relative poverty' class which has existed all along, has only been referred to as the 'new poverty class since the IMF crisis.

The increase of new poverty meant the destruction of the middle class, and furthermore was a major cause of social polarization. Polarization deepened the gap between social classes, and income polarization was connected to opportunity polarization, which directly influenced social exclusion $^{5}$. One of the social causes bringing polarization

Although the Contractual Workers Protection law was implemented in July 2007, no conditional dead line for compliance was given, which will create concern about the increase in contractual work.

5) According to a joint report by the Korea Health and Social Research Institute and the Korea Labor Research Institute, relative poverty (under the $50 \%$ of average income) ratio has risen by $0.45 \%$ from $15.97 \%$ in 2005 to $16.42 \%$ in was neoliberalistic government policy. Through restructuring, the flexibility of market demand, retrenchment, and reduction of welfare expenditure, the government financial burden should be reduced. In Korea, the middle class will be destroyed and problems for the poor will become more serious unless currently low welfare expenditure levels are increased. Therefore, if Korea is to overcome this problem it must find suitable Korean solutions. Speculative investment in the property market is problematic as it encourages polarization in Korea, and it is one of the most serious social problems, for it is wholly against the capital accumulation principle, and thus the capital system and the market distribution order are disturbed. Speculative investors in the property market aim to earn an income without working; possession of a property, which earns an income from the difference between the cost of the investment and the current value, is the most serious entrenched problem and it is the principal cause for polarization ${ }^{6)}$ in Korea.

It is vital to carry out social restructuring to overcome the problems of the 'working poor' and polarization, and rather than a macroscopic approach, improved quality of self-support enterprises, creation of work, constructing a safety net, bolstering social enterprise, and the construction of business/university cooperation systems are needed. In addition there should be cooperative programs between permanent jobs and contractual jobs, the establishment of cooperative relationships between large, and small and medium size enterprises as partners, participation in self support work motivational programs, and reformative efforts by small and medium enterprises. (see Kim Young-Hwa, 2006).

\section{Low Birth Rate and Ageing Population}

When new social risk is discussed, the most dangerous issues are the low birth and the ageing population. This means a decrease in the working population and an increase in pension beneficiaries that indicates an imbalance in the population and, further, an important deficiency between the current generation and the future generation. This will lead to social breakdown and further social erosion.

When we examine birth rates of major countries, as indicated in the following [Table 5], Korea records 1.08 in 2005, the lowest birth rate, which demonstrates its seriousness. Compared TFR 2012 with 2002, all countries have been raised as well as OECD average

2006: market earnings criteria of urban households. This figure is the highest since 1999 when the first relative poverty related survey was published. The whole household, including one person household, relative poverty ratios reaches $18.45 \%$ compared with market earnings criteria, i.e. one in 5.4 persons comes under relative poverty.

6) According to a report, "The Land Ownership Situation in 2006" by the Ministry of Government Administration and Home Affairs, 1\% (approx 500,000 people) of the population owns $56.7 \%$ of the individually owned land in Korea which reveals a seriously disproportionate tendency in land ownership 
Table 5. Total Fertility Rate (TFR) in Major Countries

\begin{tabular}{|c|c|c|c|c|c|c|c|c|c|c|}
\hline Country & USA & France & Finland & UK & Japan & Germany & Sweden & Poland & Korea & $\begin{array}{c}\text { OECD } \\
\text { average }\end{array}$ \\
\hline TFR2002 & 2.01 & 1.89 & 1.72 & 1.64 & 1.32 & 1.31 & 1.25 & 1.24 & 1.17 & 1.60 \\
\hline TFR2005 & & & & & & & & & 1.08 & \\
\hline TFR2012 & 2,06 & 2,08 & 1.73 & 1.91 & 1.39 & 1.41 & 1.67 & 1.31 & 1.23 & 1.70 \\
\hline
\end{tabular}

Note: Figures above from Major Nations and OECD average in 2002 and from Korea in 2005.

Source: Statistics Bureau, KOSIS: OECD, Society at a Glance: OECD Social indicators, 2005

Source: CIA World Fact book 2012.

In Korea, even until 2002, 'the one child one family campaign' was prevalent, even though the birth rate was 1.17 at that time. This reveals how inappropriate the population policy in Korea was and how it was heading in the wrong direction.

However, if birth rate is only studied as a population problem it is a difficult task to solve. If it is approached as the problems of women and the family, solutions can be found in the long term. The cause of low birth rates is directly connected to birth and child rearing for women and it is related to housework and economic activities of women. At present, the economic activity of women is well over $50 \%$, and if a policy were enacted treating women as housewives only, the policy would fail. The proponent suggests that continuing to operate policies on a trial and error basis will fail unless the problem of low birth rates is tackled as part of an equal policy for both sexes i.e. not just on a male bread winner model but a model where both sexes are treated as income earners, a family coexistence policy.

As the aged population rate rises, ageing becomes a serious problem because of the burden of supporting them. Due to the extension of average life expectancy, Korea has become an aging society with $7 \%$ of the population reaching the elderly age range in 2000 and $9.3 \%$ in 2005; the 14\% predicted for 2018 will be the start of an aged society, and the $20 \%$ for 2026 will create a super aged society.

\section{Conclusion: The Korean Social Welfare Task from the Critical View Point}

As studied above, Korean Social Welfare began as emergency aid work focusing on war refugees and orphans. Aid work in care centers financed by foreign aid is different from the distribution policy for workers in Germany and different again from the UK, which was aiming to promote the whole nation's quality of life. The USA, the most passive of among industrialized nations, focused on maintaining a minimum livelihood threshold with their social security system; its social welfare system had a different historical beginning and a different social background.

In Korea, welfare started by focusing on the socially weak, the socially fragile and those misfits with residual and emergency aid needs. The welfare system for the nation's quality of life and labor welfare for workers began to emerge gradually in the 1990s after experiencing changes in the social environment and economic crises. Therefore, as a nation ranked $10-12^{\text {th }}$ for GDP among OECD nations, the welfare system is very weak and the welfare budget is seriously inadequate, compared with other nations.

According to the following [Table 6] showing social security expenditure relative to GDP in OECD nations during 2002 2004, Korea is much lower than the OECD average and is the lowest ranked country other than Mexico. In the year 2009 Korea is still the same level as lowest one before Mexico. 
Table 6. OECD nations' Social Welfare Expenditure relative to GDP (unit: \%)

\begin{tabular}{|c|c|c|c|c|c|}
\hline Country & 2000 & 2001 & 2002 & 2004 & 2008 \\
\hline Austria & 14.8 & 14.8 & 14.7 & 19.2 & \\
\hline Canada & 4.9 & 5.1 & 5.2 & $10.4(a)$ & \\
\hline Finland & 12.1 & 12.4 & 12.2 & 16.8 & \\
\hline Norway & & & & & 21.6 \\
\hline France & 16.2 & 16.2 & 16.3 & 17.7 & 29.2 \\
\hline Germany & 14.8 & 14.6 & 14.5 & 19.2 & 26.7 \\
\hline Italy & 12.4 & 12.3 & 12.5 & 17.3 & \\
\hline Japan & 9.9 & 10.3 & 9.9 & - & 18.6 \\
\hline Korea & 3.9 & 4.4 & 4.6 & 2.3 & 8.3 \\
\hline Mexico & 3.0 & 3.2 & 3.2 & - & \\
\hline Sweden & 14.8 & 15.3 & 15.1 & 10.9 & 29.4 \\
\hline Switzerland & 7.4 & 7.7 & 7.8 & 2.3 & \\
\hline Turkey & 6.1 & 7.6 & 6.1 & - & \\
\hline UK & 6.3 & 6.3 & 6.1 & 13.4 & \\
\hline USA & 6.9 & 7.0 & 6.9 & $12.0(\mathrm{a})$ & 15.9 \\
\hline OECD Total & 9.3 & 9.4 & 9.3 & & 20.6 \\
\hline OECD America & 4.9 & 5.1 & 5.1 & & \\
\hline OECD Pacific & 3.5 & 3.7 & 3.6 & & \\
\hline OECD Europe & 10.9 & 11.0 & 10.9 & & \\
\hline EU 15 & 11.5 & 11.6 & 11.4 & & \\
\hline
\end{tabular}

Source: OECD Revenue Statistics each year in 2001, 2002 and 2003.

Source for 2004: National Accounts of OECD Countries, OECD, Paris, 2005a, 2003.

Source for 2008: The Korea Institute for Health and Social Affairs(KIHASA)

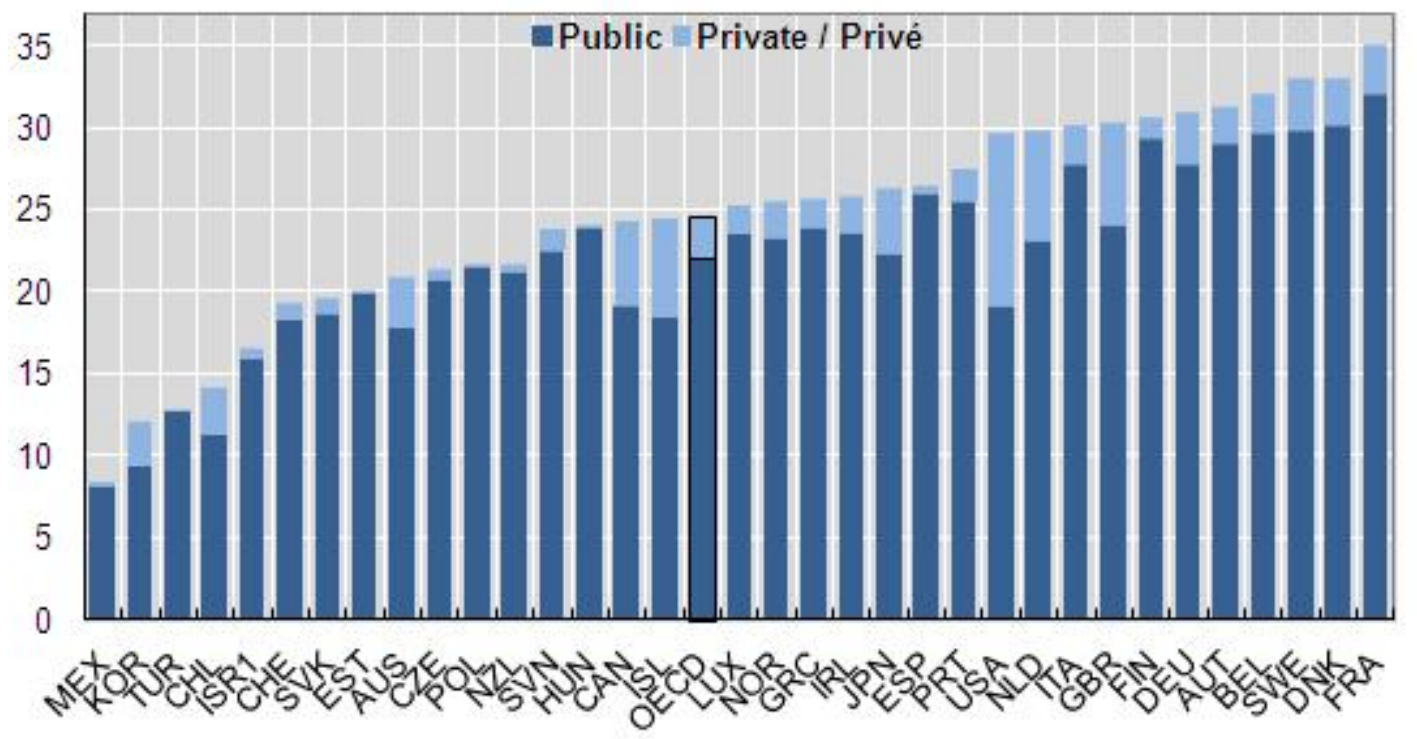

http://www.oecd.org/social/soc/socialexpendituredatabasesocx.htm

Public and private social expenditure in percentage of GDP in 2009

The task for Korean Social Welfare can be analyzed critically into five categories. Firstly, the nation's sympathy and approval must be sought for a particular welfare system. As previous governments had used social welfare as a platform for gaining political power and legitimacy, often unrealistic pledges were made but then either abolished during the implementation stage, if achievement was impossible, or they tried unreasonably to implement unworkable policies. For example, the intent of the pension system was to 'pay less and get more', but at present the worries over the dried up pension fund make the nation anxious and the issue more burdensome. Due to the nation's distrust of the government and politicians, a much needed debate is being repeatedly rejected by the people and judged as political party interests or political strategy, which means that it is not going to be easy to persuade the people of the need for new enactments and implementations.

Secondly, it is necessary to increase the people's level of 
awareness of welfare issues. When nations with about 200 years of welfare history are examined, civil class formation and civil society experiences raise welfare awareness to high levels. As welfare awareness comprises characteristics of solidarity, wealth re-distribution cooperation between generation and class, awareness of the problem of the gap between rich and poor and polarization, community spirit, and mutual cooperation, the lack of experience in civil class formation and civil society development means Koreans are used to being responsible for and solving their own problems individually, under the governmental principle of laissez -faire. This does not inspire solidarity between class and generation against social dangers, and does not cultivate social cooperation and community spirit. Also, it discourages citizens from demanding their rights against the government, or to demand a social re-distribution system between the rich and the poor to tackle the gap between them. The independent spirit of solving problems on an individual, family, and close relatives basis can be viewed as a most important principle, but if problems (e.g. unemployment, disease, social victims etc) which cannot be resolved on the individual level are nevertheless forced to be solved individually, the level of our welfare awareness as a nation is can be seen to be very low, and social welfare policy, which must have the people's understanding and agreement will have to experience a long process of trial and error in establishing a social welfare system.

Thirdly, it is necessary for policy-makers to be aware of the problems in the Korean welfare system, and to have professional knowledge and accomplishments, and the power of decision-making on social welfare policy. Policy-makers are not only politicians but also comprise professionals, professors, social workers, motivated citizens, and journalists. How this body of people thinks, judges and behaves greatly influences society. To promote and solve social issues, policy-makers must realize the importance of their behavior and they must contribute to welfare development through suitable social activity and well-informed judgments on welfare issues.

Fourthly, an effort is needed to increase the level of expenditure on welfare. As welfare finance primarily derives from the nation's taxes, it is important to carry out taxation through a fair system as acknowledged by the people. If a system is in place where an individual's income is not clearly accountable, it encourages people's mistaken perception of their cleverness in evading the payments of their due taxes which will result in the eventual collapse of the tax system. In addition, in order to devise systems of taxation that prevent tax leakage by the privileged social class $\mathrm{s}$, it is necessary to make a tax and welfare system which will largely benefit the socially weak. Many fields have been unfairly neglected by the tax system, and this needs to be amended. Payment of tax must produce visibly evident social benefits for the individual. Apart from individual taxation, contributions from enterprises are made and once contributed, for whatever reason, it becomes social property, and therefore it must be spent fairly.
Fifthly, it is necessary to develop a Korean social welfare model. In the past, Korean social welfare models have been developed, but received criticism that they did not suit reality. From 'The Establishment and Policy Direction of the Korean Welfare Model' by the Korea Institute for Health and Social Affairs in 1995 via 'Vision 2030' published in August 2006 to 'Korean Employment-Welfare Model' in 2013, Korea has attempted several times to develop a Korean welfare model, but a practical device must be developed through a lot of research and investigation in to more specific and realistic methods.

Korean welfare model development needs to solve the problem of the right to survival of the socially deprived class and the socially weak, and social welfare policy and social services must be developed as a priority so as to guarantee their minimum livelihood expenditure to improve their quality of life. A welfare policy that includes the minority in social solidarity, and an intelligent, mature welfare policy which fosters integration, equality and unity, and allows for the continuous development of social welfare policy, must be the primary focus (see Kim Young-Hwa, 2005).

In future, social welfare must be a pivotal policy of the government to enable it to recover its legitimacy and trust, and in implementing this there will be a greater sense of national unity and duty. Accordingly, I expect the Korean welfare model to be a driving force in the development of a multi-cultural society and in resolving the North-South division and confrontation and regional conflicts and divisions through regional solidarity.

\section{REFERENCES}

[1] Chossudovsky, M/ Lee Dae-Hoon translation (1997) Globalization of Poverty, Seoul: Dang Dae publishing company.

[2] Ha, Sang-Lak (1989) Korean Social Welfare History, Seoul: Park Young Sa Publishing Company.

[3] Jessop, Bob et.al. (1991) The Politics of Flexibility-Restructuring State and Industry in Britain, Germany and Scandinavia, Englland Elgar.

[4] Jessop, Bob (2002) The Future of Capitalist State, Polity Press Ltd., Cambridge

[5] Kim, Sung-Ku et.al. (1998) Globalization of Capital and Neo-liberalism, Seoul: Moon Hwa Gwa Hak Sa publishing company.

[6] Martin, Hans et.al./ Kang Soo-Don translation (1996) Trap of Globalization, Seoul: Young Lim Cardinal publishing company.

[7] National Welfare Planning Board (1995) Quality of Life, Basic Design of National Welfare for Globalization.

[8] Kim, Young-Hwa,et.al. (2005) Social Welfare Policy for the Realization of Social Justice, Seoul: Sam Woo Sa publishing company. 
[9] Kim, Young-Hwa (2006) "Globalization and Polarization: Current Tendency and Prospects", Journal of Critical Social Welfare, Vol.22, Academy of Critical Social Welfare

[10] Kim, Young-Hwa (2007) Political Economics of Social Welfare in Korea, Seoul: Yang seo won publishing company.

[11] Sohn, Ji-A, (2006) "Research on "New Poverty" in Korea With the focus on analysis on Labor Panel Sources", Ph. D thesis, College of Liberal Arts, Kyungpook Nat'l Univ.

[12] Soros, G. / Hyeong Seon-Ho translation (1998) Crisis of World Capitalism, Kim Young Sa publishing company.

[13] The Korean Academy of Social Welfare (2007) The Academy of Social Welfare 50 ${ }^{\text {th }}$ Anniversary, 1957-2007, the $50^{\text {th }}$ Anniversary, the Publication Committee.

[14] Vic George \& Paul Wilding, Kim Young-Hwa et.al. translation (2004) Globalization and Human Welfare, Seoul: Sam Woo Sa publishing company. 